\title{
Covid - 19 Sürecinde Türkiye Cumhuriyeti Sağlık Bakanı Fahrettin Koca'nın Kişisel İmaj Ögelerini Belirlemeye Yönelik Bir Saha Araştırması
}

\author{
DOI: 10.26466/opus.817635
}

\author{
Zülfiye Acar Şentürk* - $\underline{\text { Ali Mutlu ** }}$ \\ * Doç. Dr, Uşak Üniversitesi, İletişim Fakültesi, Uşak/Türkiye \\ E-Posta: \\ ORCID: 0000-0003-2606-3547 \\ ** Öğr. Gör., Uşak Üniversitesi, İletişim Fakültesi, Uşak Türkiye \\ E-Posta: ali.mutlu@usak.edu.tr \\ ORCID: $\underline{0000-0002-4961-3276}$
}

Öz

Günümüzde özellikle kamиoyu önünde devaml suretle bulunan politikacılar, sanatçılar, sivil toplum örgütü temsilcileri ve kanaat önderlerinin imaj çalısmalarnna büyük önem verdikleri görülmektedir. Söylemlerinin etkisini arttırmak, eylemlerine olan inandırıcllğ̆ yükseltmek, halk nezdinde daha fazla karşıllk bulmak için imaj çalışmalarına büyük önem veren bu aktörlerin; sözlü, sözsüz iletişim, yazma, sunma, dinleme, karakterleri, alanları hakkında yeterlilikleri, davranışları, eylem ve söylemleri kişisel imajlarını oluşturmaktadır.

Kişisel imajı oluşturan özelliklerden hangilerinin katılımcilar tarafindan daha fazla önemsendiğini ortaya koymak amacıyla Covid - 19 sürecinde dikkatin verildiği, açıklamalarının merakla beklendiğgi Türkiye Cumhuriyeti Sağlık Bakanı Fahrettin Koca'nın kişisel imajıyla ilgili saha araştırması yapılmıştır. Yöntem olarak alan araştırmasının yapıldığı çalışmada, Tesadüfi örneklem tekniğiyle Uşak Üniversitesi İletişim Fakültesine devam eden 447 öğrencinin görüşü online anketle alınmıştır. Katılımcılardan; imaj ve kişisel imaj konuları hakkında genel bir kanaat belirtmeleri istenmiş, ardından öğrencileri tarafından Sağlık Bakanı Prof. Dr. Fahrettin Koca'nın kişisel imajını oluşturan etkenlerin önem düzeyi ortaya çıkarılmaya çalışılmıştır.

Araştırmaya göre Sağlık Bakanı Fahrettin Koca'nın kişisel imajının Uşak Üniversitesi İletişim Fakültesi öğrencilerinin algısında büyük ölçüde olumlu olduğu sonucuna ulaşılırken; bu olumlu imajın oluşmasinda sözlü iletişim faktörlerinin, karakter faktörlerinin ve sözsüz iletişim faktörlerinin büyük oranda etkili olduğu bulgusu elde edilmiştir.

Anahtar Kelimeler: Imaj, Fahrettin Koca, Covid 19 


\title{
A Field Study To Determine Personal Image Elements Of Fahrettin Koca, Minister Of Health Of The Republic Of Turkey, During The Covid-19 Process
}

\begin{abstract}
Today, it is seen that politicians, artists, NGO representatives and opinion leaders, who are constantly in front of the public, attach great importance to image work. These actors, who attach great importance to image studies in order to increase the influence of their discourse, to increase the credibility of their actions, to find more response in the perception of the public; verbal and nonverbal communication, writing, presenting, listening, characters, competencies about their fields, behaviors, actions and discourses constitute their personal images.

In order to establish which ones are more regarded by the participants of the features that make up a personal image of Covid - 19 process in, attention was paid and explanations were awaited, the Republic of Turkey are expected to description Health Minister Fahrettin Koca was done field research on the personal image. In the study in which field research was conducted as a method, 447 students studying at Uşak University Faculty of Communication with the random sampling technique participated in the online survey. From the participants; they were asked to express a general opinion on the issues of image and personal image, then the Minister of Health Prof. Dr. The importance level of the factors that make up Fahrettin Koca's personal image has been tried to be revealed.

According to the research, it was concluded that the personal image of the Minister of Health Fahrettin Koca was mostly positive in the perception of the students of the Faculty of Communication of Uşak University; It was found that verbal communication factors, character factors and non-verbal communication factors are largely effective in the formation of this positive image
\end{abstract}

Keywords: Image, Fahrettin Koca, Covid 19 


\section{Giriş}

İmaj kavramı bir ürünün, markanın, politik kişiliğin ya da ülkenin kamudaki algılamasını/görünümünün dikkate alınması olarak nitelendirilir (Uztuğ, 1999, s.138). Özellikle seçim kampanyalarında, kriz yönetimlerinde, profesyoneller tarafindan yürütülen imaj çalışmaları halk nezdinde daha fazla karşılık bulmak için yoğun bir şekilde planlı olarak sürdürülmektedir.

Kişisel imajı oluşturan etmenler arasında görüntü, sözlü iletişim (konuşma ve ses kullanımı), sözsüz iletişim (beden dili, zaman ve mekân kullanımı, giysiler, genel görüntü, renkler, çevre ve aksesuarlar), karakter, karizma, özgüven, özsaygı, yeterlilik, birikim, potansiyel, kişisel gelişim, deneyim, dikkat çekicilik, davranış ve tavırlar gibi unsurların önemli olduğu görülmektedir. Aynı zamanda aday imajının karakter bileşeni; adayın insanlarla etkili iletişim kurma kabiliyeti, huyları, yöneticilik vasıfları, zekâ ve bilgi düzeyi, ahlak anlayışı, yaptırım gücü, iş bitiriciliği, kamu yönetimi tecrübesi, önceki faaliyet ve icraatları, gündemdeki tartışmalar hakkındaki siyasal yorumları gibi niteliklerden oluşmaktadır (Balcı, 2003, s.153). (Silinecek)

Böylesine önemli bir kavram özellikle kriz dönemi olarak görülen pandemi sürecinde daha da önemli hale gelmiştir. Dolayısıyla bu kadar yoğun bir dönemde Covid 19 sürecini yöneten Sağlık Bakanı Prof. Dr. Fahrettin Koca'nın kişisel imajını nelerin oluşturduğu ve imaj oluşumuna katkı sağlayan etkenlerin ne denli önemli olduğu ölçülmeye çalışılmıştır. Aynı zamanda bu çalışma; eylem ve söylemleri dikkatle takip edilen, açıklamalarına geniş yer verilen, yazılı ve sözlü ifadelerinin merakla beklenildiği Sağlık Bakanı Fahrettin Koca'nın kişisel imajını Uşak Üniversitesi İletişim Fakültesi öğrencilerinin nasıl algıladıklarını ortaya koymak amacıyla yapılmıştır.

\section{İmaj Kavramı}

İmaj, bir obje ya da kişi hakkında diğerlerinde olan inanış, düşünce, his ve izlenimlerin birbiriyle olan etkileşimleri sonucu ortaya çıan bir durumdur (Zey ve Ferrell, 1981, s.189). Kelime, Latince resim veya görüntü anlamına gelen "imago" kökünden gelmektedir. Bireyin zihninde her şey ile ilgili oluşan bilişsel/algısal ve psikolojik bir görüntü ya da resme karşllık gelmektedir (Dinçer, 1998, s.7). Bireylerin nesneler ve kişiler hakkında kişisel olarak 
zihinlerinde oluşturdukları durumdur ve önceden edinilen bilgilerle bu bilgilerin etkileşimiyle anlam bulur. Birey, nesne ya da kişiyle ilgili olarak sahip olduğu imajdan hareketle tavır ve düşüncesini ortaya koymaktadır (Taslak ve Akın, 2005, s.263). İmaj, kitle iletişim araçlarından aktarılan farklı mesajlardan doğal (informal) ilişkilere, toplumun özelliklerinden, önyarg1lara kadar birçok kaynaktan elde edilen bilginin değerlendirilip yorumlanmasıdır (Ünüsan ve Sezgin, 2005: 166). Özetle, insan zihnindeki başka insanlar, olaylar, kurumlar ve birçok şeyle ilgili oluşan izlenimlerin toplamıdır (Linkemer, 1997, s.6). Çünkü birey jest, mimik, giyiniş tarzı, hareketler, konuşma biçiminden yola çıkarak bıraktığ 1 izlenim ve sonrasında oluşan resim ile hatırlanmaktadır (Türkkahraman, 2004, s.7).

İmaj bir süreçtir, kişi, nesne ya da durumlarla ilgili olarak düşünce ve yorumların oluşturulması çabası olarak algılansa da medyanın da etkin kullanılmasıyla birlikte istenilen düşünce ve davranış biçiminin oluşturulması planlı ve uzun vadeli bir etkinlik olduğu için süreçtir. Bu özelliği nedeniyle imajın, insanlar tarafından nasıl bilindiği, hatıllandığı ve konu hakkındaki yorumlar ve kurulan bağın biçimiyle ilgili olduğunu söylemek mümkündür (Robins, 1999, s.21).

İmajin oluşumunda bireylerin kendi hissettikleri ve dışarıdan gelen mesajların nasıl yorumlandığı önemlidir (Gemlik ve Sığrı, 2007, s.268). Bununla ilgili olarak ise; içsel faktörlerin başında bireyin kişi ve nesne hakkındaki "bilgilenme düzeyi"; kişiler ya da nesnelerle ilgili olarak "sahip olduğu yarg1" gelmektedir. Dışsal faktörler olarak ise bireyin içinde bulunduğu toplumun kültürel ve siyasi yapısı, ekonomik yapıdan tarihsel zenginliklerin içinde olduğu birçok unsuru barındıran "olanaklar ve hizmetler" gelmektedir. Dolayısıyla imaj genellikle algılandığı şekliyle, yapılan tasarım ve reklamlar aracilığıyla oluşturulan ve dış görünümle ilgiliymiş gibi oluşan alg1dan farklıdır (Tolungüç, 2000, s.23). Modern yönetim kuramlarında da görüntünün çok boyutlu doğası, somut olmayan yönleri ve sürdürülebilirlik vurgulanmaktadır (Oržekauskas ve Šmaižienė, 2007, s.91 ). İmajın oluşumunu kurumların donanımı, kurumsal tutum ve davranışları etkilerken, dış görünüm, beden dilinin nasıl kullanıldığı, davranışların sergilenme biçimi ve fiziksel ortamın şartları bireysel imajı tamamlayan faktörlerdir (Peltekoğlu, 1997, s.126).

İmajın özelliklerinden biri de bireylerde ilgili nesne ya da kişilerle ilgili duygusal bir değer oluşturmasıdır. Bu değer de diğerlerine karşı üstünlük 
şansı anlamına gelmektedir. "Davranış kimliği", "iletişim kimliği” ve "görsel kimlik" uygulamaları aracılığı ile sunulan mesajlar, hedef kitleler tarafından algılanarak zihinlerinde belirli bir resmin belirginleştirilmesiyle imaj oluşum süreci başlatılmaktadır (Tosun, 2003, s.174). Bu sürecin etkin olduğu alanlardan birisi kitle iletişim araçlarıdır. Bu araçlarla insanların zihinlerinde imaj oluşturulması kolay ve etkilidir. Kitle iletişim araçlarının bu sürece katkısının başında bireylerin izlediği ve duyduğu durumla ilgili olarak kendisinde var olan algıyı güçlendirip, yargılarını pekiştirmesi gelmektedir. Bu katkıyı sağlamak da duruma izleyicilerin ilgisini çekebilmek için anlatım ve görüntülerin özenle seçilmesi ile gerçekleşmektedir (Rivers, 1982, s.213). Son yıllarda, halkla ilişkiler araştırmaları sadece görünürlüğün yetmediğini, imajı yönetmenin iki ana unsuru olduğunu ortaya koymaktadır. Bunlar tanınırlık oluşturma ve güvenilirlik yaratmaktır (Oržekauskas ve Šmaižienė, 2007, s.92). Bunu sağlamak için özellikle kurumsal düzeyde iç ve dış hedef kitlelerle kurulan bireysel ya da kurumsal iletişimin şekli de imajın nasıl olacağını belirlemektedir (Ak, 1996, s.193).

İmaj kavram olarak dinamik, değişken ve aynı zamanda da karmaşık bir kavram olması nedeniyle (Rao, 1994, s.33), birçok faktörden etkilenmektedir. Bunların başında kurumun sosyal yapısı, tarihsel değerleri ve kişisel tecrübeler gelmektedir. Bireysel anlamda ise, bireyin aldığı mesajları kendi deneyimleri ile de birleştirerek çok yönlü ve karmaşık bir süreçten geçirmesi belirleyicidir (Zey ve Ferrell, 1981, s.189). İmaj insanların deneyimine bağlı olarak farklı şekillerde ortaya çıksa da iyi imaj elde edilen bir durumdur (Peltekoğlu,1997, s.126). Bu nedenle imaj izlenimden ayrı olarak planlı ve sistemli çaba gerektiren bir alandır. İmaj öncelikle belirli bir politikacı veya bir siyasi parti hakkında sahip olunan görsel temsile dayanmaktadır. Bu anlamda görüntü, fotoğrafçılığın ve daha sonra kameranın izleyiciye/alıcıya belirli bir politikacı hakkında nasıl göründügü ve sözlü veya sözel olmayan durumlarda nasıl davrandığı hakkında tarafsız bir görüntü sunduğu fikrine dayanmaktadır. Bu bağlamda, bir kapak sayfasında hızlı ve kolay bir şekilde görülebilen bir fotoğraf politikacıların konuşmalarından ve onlar hakkında veya onlar tarafından yazılmış makalelerden çok daha fazlası anlamina gelmektedir (Sharlamanov ve Jovanoski, 2014, s.599). 


\section{Kişisel İmaj}

"Kişisel imaj" kavramı; kişinin, kendi içsel iletişimiyle tanıdığı kendisini, iletişimin imkanların kullanarak niteliklerini, özelliklerini, değerlerini olabildiğince iyi bir şekilde karşı tarafa aktarabilmesidir (Wright ve Fill, 2001, s.101).

Kişisel imaj kişinin kendisine ait imajdır. Bireylerin tanınmalarını hatta diğerlerinden ayrılmalarını sağlayan özelliklere ve ilkelere sahiptirler. Bu yüzden kişisel imaj bireyin sahip olduğu öz imajı, başkaları tarafından alg1lanan imaji ve yansıtmak istediği imajla birlikte diğer tüm unsurların toplamının bir bütünüdür (Sampson, 1995, s.12). Bu faktörlerin etkileşimiyle oluşan kişisel imaj, kişi hakkında, diğer kişi ya da kişilerin düşünce ve davranış şeklini belirlemektedir. Kişinin farkında bile olmadan kendi hakkında başkalarında oluşturacağı imaj, olumsuz düşünce ve duygular başta olmak üzere, tutum ve davranışların da oluşmasına neden olmaktadır. Bu nedenle kişi hakkındaki oluşan düşünce ve fikirler, duygular, tavır ve davranışlar kişisel imajin etkisiyle oluşmaktadır. Dolayısıyla kişinin kendi imajının farkında olup kontrol edip yönetmesi mümkündür. Farkında olunmayan ve sonucunda yönetilemeyen imaj kişinin özel hayatında olumsuzluklara ve engellere neden olmaktadır (Çakır, 2005, s.28). Kişisel imaj kişinin kendisini olmadığı, olmayı hayal ettiği birisi gibi göstermesi değil, kendisini etkili ve doğru bir biçimde ortaya koymasıdır. Duruma ve ortama göre imaj oluşturmak adına maskeler takmak, farklı kimliklere bürünmek imaj olmadığ 1 gibi kişi hakkında olumsuz düşüncelere neden olabilecek bir durumdur (Özer, 2008, s.221). Kişisel imaj, bireyin kendisini yeterince tanıyıp farkında olmasıyla ve kendisini kabul etmesiyle başlamaktadır. Bu tanıma süreci bireyin kendisini başkalarına da dürüst ve açık bir şekilde ifade etmesiyle ile devam etmektedir.

Bireyin, bir diğer kişiyi zihninde canlandırması sırasında onun kendisinde bıraktığı tüm etkilerden faydalanılmaktadır. Bu etkilerde giyim tarzı, yaşam şekli, hayata ve diğer insanlara bakışı, birey olarak yapıp ettikleri belirleyici olmaktadır. Kurumsal anlamda ise, üretilen ve sunulan ürün ve hizmetler, üretim biçimleri, çevre ve toplumun ne kadar önemsenip önemsenmediği ve kurumun üstlendiği roller belirleyici olmaktadır (Tengilimlioğlu ve Öztürk, 2004, s.229). Kişiler hakkındaki imajın değerlendirilmesi; kişinin iyi, bilgili ve eğlenceli gibi yönlerinin vurgulanması olurken, kurum- 
larla ilgili olarak sahip olduğu imkanlar, müşterilerine yansıttıkları ve hedef kitleleri ile iletişim biçimlerinin nasıl olduğu şeklindedir (Tolungüç, 1992, s.11). İmaj yönetiminin kendileri için öneminin farkında olan kişi ve kurumların aslında ilk yaptıkları sahip oldukları artı ve eksi yanları tanımlayıp bunları net bir şekilde ortaya koyabilmektir. Bu değerlendirme ne kadar objektif yapılırsa iyi bir izlenim için nelerin gerekli olduğunu tespit edebilmek de o kadar gerçekçi olmaktadır. Aksi durumda davranan kişi ve kurumların yaptıkları ise diğerlerinin üzerindeki ilk izlenim ve bıraktıkları etkinin nasıl olduğuna önem vermeden, yeterli özen ve hassasiyeti göstermeden (Peker ve Aytürk, 2002, s.127) davranmalarıdır.

Kendi benliklerine olan saygının olumlu bir imajı yansıttı̆̆ının farkında olan bireyler, kendisini ifade şekline özen gösterdikleri için başkalarının onlar hakkındaki izlenimlerini stratejik olarak yönetme olasılıkları daha yüksektir (Rui ve Stefanone, 2013, s.1287). Kişisel imaj, sadece bireyin kendisi için değil, kurumlar için de önemlidir ve kariyer için önemli bir unsur haline gelmiştir (Ayhan ve Karatepe, 1999, s.46). Öyle ki artık kişisel imaj da yönetilmesi gereken bir alan haline gelmiştir. Bunun farkında olan kişi ve kurumların imajın yönetilmesiyle ilgili planlarının da olması gereklidir. Özellikle profesyonel yaşamda bireylerin kendilerini değerlendirip yönetebildikleri imajları ile toplumda fark edilmeleri ve daha iyi bir konuma sahip olmaları gerekmektedir.

Sosyal bir varlık olan birey ev, okul, iş hayatı nerede olduğu fark etmeksizin, bir başkasıyla fikir alışverişi için bile olsa iletişim halinde olacağı için bu süreçteki tavrı, bilgisi, konuşma yeteneği, inisiyatif alması önemli hale gelmektedir. Yaşı, cinsiyeti, konumunun ne olduğundan çok o anda sunduğu görüntü önemlidir ve bu da bireye katkı ve fark sağlamaktadır (Rasband, 2000, s.1). Bu fark hem bireysel hem kurumsal anlamda itibar oluşturmaktadır. İtibar imajın yansıması olarak diğerlerinden kişi ya da kurumla ilgili olarak geri bildirim alınmasıdır. Alınan bu geri bildirim aynı zamanda kavram olarak imajı çift yönlü iletişimin uygulamalarından biri haline getirmektedir (Whetten ve Mackey, 2002, s.400). Ayrıca imaj yönetiminin farkına varılmasıyla bireylerin kendilerine başarı sağlayan davranışlarının farkında olarak diğerlerinden vazgeçmeleri mümkün olmaktadır (Peker ve Aytürk, 2002, s.128). Toplumsal şartlardaki değişim ve dönüşüm aslında görsel imajların önemini arttırmaktadır. Böyle durumlarda siyasetçiler başta olmak üzere özellikle toplumda söz sahibi olanlarda ilk dikkat edilen giyim 
ve duruş şekillerdir. Başkaları hakkındaki oluşan ilk düşünceler görsel öğeler yoluyla olduğu için görünüm ve beden dili etkilidir. Dolayısıyla görsel bilginin iyi bir biçimde yorumlanarak aktarılması gerekmektedir (Sampson, 1995, s.17). Güçlü, olumlu ve desteklenmiş bir imaj profesyonel yaşamın yanı sıra insan ilişkilerinde de istenilen sonuçları vermesi açısından önemlidir. Olumlu bir imajla bireylerin kendisine olan güvenleri artmaktadır. Bu nedenle bireylerin gündelik hayatlarında göz ardı ettikleri imaj kavramı ve imajı oluşturan unsurların neler olduğunun öğrenilmesi önemlidir (Barutçugil, 2006, s.45). İmaj kavramı genelde gündelik hayattan çok profesyonel hayat ve siyasette kullanılmaktadır. Dolayısıyla imajı oluşturan unsurlar da siyasetçi ve seçmen üzerinden oluşturulmaktadır. İmaj, gerçeğin somut ve soyut bir biçimde temsili, daha genel tanımla, gerçeğin yeniden üretilmesidir (Tolungüç, 2000, s.23). İmaj politikada ve adayla birlikte kullanıldı̆̆ında ise; ön plana çıkan kısmı duyusal öğedir. Bu da karizma, güven, tavır gibi tanımlanamayan ancak aday ve seçmenleri arasındaki olgulara karşılık gelmektedir (Y1ldı, 2000, s.29).

\section{Kişisel İmajın Unsurlan}

Kişisel imaj kişiyle ilgili farklı özelliklerden oluşmaktadır. Bu farklı özellikler görüntü, ses, tavır, davranış gibi kişisel özellikleri barındırmaktadır.

Kişisel imajın oluşturulmasında etken olan öğeler şunlardır (Çakır, 2005, s.27):

- Kişinin görüntüsü.

- Sözlü iletişim, bu daha çok konuşma ve ses kullanımının nasıl olduğuyla ilgilidir.

- Sözsüz iletişim, bireyin varlığını ortaya koyan ve sözlü iletişimi destekleyen tüm unsurlardır. Bunların başında beden dili, kılık kıyafet, kullanilan renkler ve aksesuarlar gelmektedir.

- $\quad$ Bireyi güçlü kılan diğer iletişim özellikleri ise yazı ve iyi bir dinleyici olma gibi özelliklerden oluşmaktadır.

- $\quad$ Bireyin karakter yapısı, burada da özgüven ve özsaygı belirleyicidir.

- $\quad$ Bireyin uzmanlık alanları, yapabildikleri gibi özelliklerden oluşan yeterlilikler.

- $\quad$ Bir diğer özellik ise davranış ve tavırlardan oluşmaktadır. 
Görüntü/İlk İzlenim: Bireyler diğerleri hakkındaki ilk yorumlarını tanıştıktan kısa süre sonra yapmaktadırlar. Bu yorum karşılaşılan şartlar, içinde bulunulan ortam, kişilerin o anki durumlarından etkilenildiği için çok sağlıklı olmasa da karşılaşılan kişi hakkında az da olsa bir değerlendirme yapılmaktadır. Çoğunlukla ilk karşılaşmada tanışılan kişinin özelliklerinde (Sampson, 1995, s.28) ; ırk, cinsiyet, yaş, görünüm, yüz ifadesi, gözler ve saç, giysiler, hareket ve duruş sıra ile ön plana çıkmakta ve değerlendirmeye alınmaktadır. Bundan sonra gelen süreç daha uzun zaman almakta ve karşılıklı etkileşimle şekillenmektedir. Bunlar ise, bireyi çekici hale getiren özelliklerin fark edilmesi, kişiliğine dair çıkarımlar, eğitimi ve başarılı olduğu alanlar ve başarının seviyesi, nezakete bakış açısı ve bunu ortaya koyması, sosyal bir birey olarak nasıl davrandığı ile ilgili olarak ortaya koyduklarıdır. Tüm bunlardan sonra ise taraflarda güven duygusunun oluşup oluşmadığı, karşı tarafın mesajlarının nasıl değerlendirileceği sonucuna ulaşılmaktadır.

İlk izlenim kendisinden sonra gelen izlenimleri de etkileyeceği ve onlar için yol gösterici hatta karar verici olması açısından önemlidir. İlk izlenim çok kısa bir sürede oluştuğu için önemlidir. Bu süre 30 saniye ile 4 dakika arasında değişmektedir. Yapılan bir araştırma sonucuna göre görüntü ve bedenin kullanım biçiminin ilk izlenimde \%55, konuşma özellikleri ve ses \%38, söylenilenler ise sadece \%7'lik bir orana sahiptir (Çakır, 2005, s.26). Kadınların görünüşleri hakkında daha fazla endişe duydukları ve fiziksel görüntülerini korumak için daha fazla motivasyon sergiledikleri bilinmektedir. Bu da toplumdaki kadın imgesinin önemini vurgulayan geleneksel imgeye dayalı değer sisteminin bugün devam ettiğini göstermektedir (Rui ve Stefanone, 2013, s.1301). İnsanlar ayrıca ilk gördükleri kişinin yüzüne bakarak oradan anlam çıkarmaya ve kişi hakkında bilgi edinmeye çalışmaktadırlar. Yüz ifadesinden çıarılan yorumlar, bireyle ilgili kararlarda ve değerlendirmelerde kullanılmaktadır. Bunun yanında kişi ile ilk izlenimin yüzdeki etkisi sonraki süreçlerde de etkili olmaktadır (Hassin ve Trope, 2000, s.839). İlk izlenim bırakmak için asla ikinci şans olmadığı için gülümsemek, nazik olmak ve karşı tarafa olumlu duygular iletmek önemlidir (Berkvens, 2009, s.55).

Sözlü İletişim: Sözlü iletişim, duygu veya düşünceleri ifade etmek veya bilgi alışverişinde bulunmak için kelimelerin veya konuşmaların veya işitsel dilin kullanılmasını içerir (https://askanydifference.com/). Sözlü iletişim, 
bireylerin kendilerini ifade etmeleri için bir fırsattır. Bireyin eksikliğini hissettiği bilgilere ulaşmasında yine sözsüz iletişime başvurulur. Şeyleri, insanları, fikirleri tanımlamak için kullanılan sözlü iletişim, kişilere başkalarını bilgilendirme ve onların görüşlerini öğrenmek için de ortam hazırlamaktadır. Sözlü iletişimin başarılı olmasında kelimelerin seçimi, ses tonu ve hızının konuya ve hedef kitleye göre belirlenmesi, sözlü iletişimi destekleyecek sözsüz iletişim unsurlarının kullanılması, konuşmada duraklamalar yapılması gibi faktörlere bağlıdır. Sözlü iletişimin en önemli avantajı konuşmacı ve dinleyicileri birbirilerini daha iyi anlama ve buna bağlı olarak da geri bildirimi etkin bir biçimde kullanma avantajı sağlamasıdır.

Sözsüz İletişim: Sözsüz iletişim duygu ve düşüncelerin aktarılmasında eylemlerin, görünüşün, nesnelerin kullanımının, ses, zaman, kokunun paylaşımıdır. Yüz ifadeleri, göz hareketleri, jestler ve vücudun duruşu, mesafe, el/kol/baş hareketleri, mekanı kullanma şekli, mimikler ve göz teması, renkler, bireyin diğerlerine kıyasla durduğu yön, dokunma ve aksesuar kullanımı sözsüz iletişimin diğer belirleyicileridir.

Beden duruşu, mesafe, el/kol/baş hareketi, mimikler, göz teması, ses tonu ve bireyin diğerlerine kıyasla duruş yönü gibi konular kişilerarası iletişimi etkilemektedir. Sözsüz iletişimde bilinçli olarak tercih edilen ve parfüm, kıyafetlerin seçimi ve tarzı, önemli aksesuarlardan olan takı-mücevher kullanımı, ışıklandırma, mobilya, koku, müzik gibi unsurlar da sözsüz iletişimin gücünü arttırmakta ve diğerleri üzerinde bırakılan etkiye katkı sağlamaktadır (Poon Teng Fatt, 1998, s.16).

Sözsüz iletişim sözlü iletişimi desteklemesi ve sözlü olarak ifade edilemeyen duyguları daha etkili bir biçimde ortaya koyması açısından önemlidir. Ayrıca sözsüz iletişim bir bütün olduğu için daha dikkatli değerlendirilmesi ve yorumlanması gerekmektedir.

Diğer İletişim Özellikleri (Yazma, Sunum ve Dinleme): Bireylerin kendilerini ifade etme şekillerinden birisi de yazmadır. Yazma eyleminde kullanılan dile hakim olma başta olmak üzere dilbilgisi kuralları, üslup, yazının iletileceği biçimin (e-posta, mektup gibi) göz önünde bulundurulması yazılı iletişimde önemlidir. Sözlü iletişime göre daha resmi ve kalıcı bir dil olan yazılı iletişimde alıcının özellikleri de göz önünde bulundurulmalıdır. 
Dinleme eylemi, iletişimin belirleyici unsurlarından biridir. Dinleme dikkat, çaba ve en önemlisi de nezaket ve sabır gerektirdiği için iyi dinleyiciler diğerlerinden ayrılmaktadır. Dinlerken dinlenilen kişiye yönelmek, dinlediğini belli etmek için göz temasını ihmal etmemek iyi dinleyicilerin özelliklerindendir. Dinleme bir yeterlilik, kazanılması gereken bir özellik olduğu için toplum içinde iyi bir yer edinmek isteyen herkesin bu konuya özen gösterip önem vermesi gerekmektedir.

Karakter (Karizma, Özgüven, Özsaygı): Karizma sözlükte “bazı insanların doğal olarak sahip oldukları, diğer insanları etkilemelerini ve dikkatlerini ve hayranlıklarını çekmelerini sağlayan özel bir güç" olarak tanımlanmaktadır. (https://dictionary.cambridge.org).

Max Weber'e göre karizma, ölçülebilir özellikleri olmayan, kendine has özellikleriyle insanların dikkatini ve ilgisini çekebilen, insanları kendisine hayran bırakan özelliklere sahip olmaktır. Karizmanın rasyonel olmayan, geleneksel olmayan ve bürokratik olmayan önemli unsurları vardır. Bunlar: olağanüstü kabiliyette bir kişilik, krizlere mücadele ederken ortaya koydukları tavırlar ve kriz için ürettikleri radikal çözümlerdir. Karizmatik özelliklere sahip bireyler, yetenekleri ve elde ettikleri başarılara bağlı olarak diğerlerinin kişiye olan güvenini de arttırmaktadır (Ray, 2011, s.57).

Bireylerin kendi yetenek ve değerinize olan inanç ve güven olan özgüven (dictionary.cambridge.org) üç bileşenden oluşmaktadır ve öz sayg1 kişinin inanç ve bilinç temeliyle ilgili olarak var olmaktadır. Kişinin düşünceleri, davranışları, duyguları ve eylemleri öz güveni ile bağlantılı olarak ortaya çıkmaktadır (positivepsychology.com) şeklinde özetlemek mümkündür.

Özgüveni yüksek olan bireylerin kendilerini tanıma, eksi ve artı yönlerini dürüst bir biçimde koyma konusunda sıkıntıları olmayacağı için kendilerine gelen olumsuz yorumlarda bile sakin kalma özellikleri bulunmaktadır. Başkalarından gelen her türlü yorumu makul bir şekilde kabul edebilen öz saygısı yüksek bireyler bu özellikleriyle diğerlerinden ayrılmakta ve toplumda kendilerini farklı bir yerde konumlandırmaktadırlar.

\section{Yeterlilikler (Birikim, Potansiyel, Kişisel Gelişim, Deneyim, Göze}

Çarparlık): Bireylerin özellikle de özgüvenle ilgili olarak kendilerini tanımaları ve eksi yönlerini artıya çevirme, kendilerine yeni özellikler katabilme 
becerisine sahip olma imaj açısından önemlidir. Kendisine uzmanlık alanı seçen bireylerin bu uzmanlık alanın besleyen ve ondan beslenen başka konularda da yeterliliğe sahip olması önemlidir. Buna ek olarak gelişimin ve değişimin farkında olan bireyler olaylar ve durumlar karşısında ortaya koydukları tavırla sadece göze çarpmakla kalmayıp, akılda da kalıcı olmaktadırlar. Herkesin birbirine çok benzediği günümüzde bireylerin deneyimi, kendilerine yaptıkları yatırım, toplumsal sorunlara karşı duyarlılıkları imajlarının olumlu bir şekilde oluşup gelişmesine katkı sağlamaktadır.

Davranış ve Tavırlar: Bireyler, Mevlana'nın dediği gibi "İnsanlar kıyafetleriyle karşılanır, İlmiyle ağırlanır, ahlakıyla uğurlanır." Kılık, kıyafeti de içine alan diş görünüm ilk izlenim için önemli olsa da izlenimin olumlu şekilde devam etmesi davranış ve tavırlarla ilgilidir. Bireysel ve profesyonel hayatta dikkat edilmesi gereken bir çok durum vardır. Bunların başında toplumun kabul ettiği nezaket kurallarına dikkat etmek başta gelmektedir. Bencillik ve egonun olmadığı davranışlar, makama ve konuma uygun davranmak, başka insanlara da söz söylemeleri için fırsat vermek, uygun hitap ve üslup gibi tavırlar da yine olumlu bir imajin olmazsa olmazlarındandır.

İmaj bireysel ya da kurumsal anlamda oluşturulmak istenildiğinde kişi ya da kurumun hangi özelliklerinin ön plana çıkarılacağı, benzerlerinden ya da rakiplerinden ayrılan yönlerinin ortaya konulması gerekmektedir. İmaj oluşumu zaman alacağı için yapılan çalışmaların planlı, sistemli ve sürekli olmasına özen gösterilmelidir. Özellikle kişisel imaj çalışmalarında bireylerin dış görünüşünden konuşmasına, olaylar karşısındaki tavırlarından sözlü iletişim özelliklerine kadar birçok unsur etkili olmaktadır. Bireyler kişi ya da kurumları değerlendirirken tüm özellikleri bir bütün olarak değerlendirmeyi tercih etmektedirler. Olumlu biçimde oluşan imaj kısa zamanda değişebilmektedir. Bu nedenle hem bireylerin hem de kurumların imaj oluşan pozitif imaj algılarını bir bütün olarak korumayı sağlayacak çalışmalara yönelmeleri gerekmektedir.

\section{Yöntem}

Yöntem olarak alan araştırmasının kullanıldığı çalışmada, Uşak Üniversitesi İletişim Fakültesi öğrencilerinin oluşturduğu katılımcllara ilk olarak imaj ve kişisel imajla ilgili genel düşünceleri sorulmuş, ardından Sağlık 
Bakanı Prof. Dr. Fahrettin Koca'nın kişisel imajinı oluşturan etkenlere verdikleri önemin hangi düzeyde olduğu tespit edilmeye çalışılmıştır.

\section{Araştırmaya Konu Olan Olay Örgüsü}

Dünya Coronavirüs hastalığının varlığından 31 Aralık 2019' da haberdar olmuştur. Çin, Dünya Sağlık Örgütü'ne Vuhan kentinde kaynağı bilinmeyen gizemli bir solunum yolu rahatsızlığının ortaya çıtığını bildirerek hastalığ ilan etmiştir.

İlk olarak Çin'de etkili olan salgının Asya sınırlarını aşarak küresel bir tehdit haline gelmesi çok uzun zaman almamıştır. Bu sürecin hızşı bir şekilde ilerlemesi, dünyanın virüsle ilgili haber ve gelişmelere odaklanmasına neden olmuştur. Tüm ülkelerin gündemi de salgının kontrol altına alınması ve önlenmesine yönelik tedbirlerin neler olacağ 1 haline gelmiştir.

Salgın Çin'de başlamasına rağmen önce Avrupa ilerleyen zamanlarda da Amerika'da yoğun olarak görülmüş ve olumsuz etkilerini gün geçtikçe şiddetlenerek arttırmıştır.

11 Mart'ta Sağlık Bakanlığı, Türkiye'de ilk vakanın görüldüğünü duyurmuştur. 12 Mart'ta Türkiye'de ilk ve orta dereceli okullar ile üniversitelerde eğitime ara verilmiştir. Ardından Türkiye'de ki kısıtlamalar genişletilerek cafe, lokanta, eğlence merkezleri, kuaför gibi işletmelerin kapatılmasıyla devam etmiştir. Salgın döneminde alınan ve alınması gereken tedbirleri ve salgınla ilgili gelişmeleri gerek kitle iletişim araçlarından gerekse de yeni medya araçlarından duyuran Sağlık Bakanı Prof. Dr. Fahrettin Koca salgın dönemin de merakla takip edilen bir aktör olmuştur.

\section{Araştırmanın Uygulanması, Evren ve Örneklem}

Alan araştırması 01 - 18 Haziran 2020 tarihleri arasında Uşak Üniversitesi İletişim Fakültesi'nde öğrenim gören 447 öğrenciyle online anket yoluyla yapılmıştır. Çalışmanın örnekleminin belirlenmesinde basit rastlantısal/tesadüfi örnekleme tekniği esas alınmıştır.

\section{Verilerin Analizi ve Kullanılan Testler}

Bulgular , SPSS 25.0 istatistik programmnda işlenmiştir. Frekans analiziyle; katılımcıların demografik özellikleri, kişisel imaj ve Sağlık Bakanı Fahrettin Koca'nın kişisel imajını algılama şekillerini, Aritmetik Ortalama analiziyle 
Sağlık Bakanı Fahrettin Koca'nın kişisel imajını belirleyen faktörlerin önem düzeylerini ölçmek, korelasyon (Correlations) ile faktörler arasındaki ilişkiyi ortaya koymak, t-testi ile yaş, cinsiyet gibi ikili bağımsız değişkenlerle kişisel imaj faktörleri arasında farklılık olup olmadığını ortaya koymak, Anova testi ile bağımsız değişkenler arasındaki ilişkiyi ortaya koymak amaçlanmıştır.

\section{Verilerin Toplanmast}

Sağlık Bakanı Fahrettin Koca'nın kişisel imajının ögelerini belirlemek amacıyla Canöz ve Canöz'ün (2014) "Cumhurbaşkanı Abdullah Gül'ün Kişisel İmajının Ögelerini Belirlemeye Yönelik Bir Saha Araştırması" adlı çalışmasında kullandığ 1 "kişisel imaj önem düzeyi belirleme ölçeği" bazı düzenlemeler yapılarak kullanılmıştır. Bu yaklaşımla üç bölümden oluşan bir anket formu oluşturulmuştur. Anketin ilk kısmında, katılımcıları demografik özelliklerini ortaya koyacak sorular sorulmuş olup, ikinci kısmında kişisel imaj ve Sağlık Bakanı Fahrettin Koca'nın görevinde başarılı olup olmadığın belirlemeye yönelik bir tane açık uçlu, dört tane çoktan seçmeli, soruya yer verilmiştir. 38 sorudan oluşan ve beşli likert ölçeğinin kullanıldığı çalışmanın üçüncü bölümünde ise katılımcılardan Sağlık Bakanı Fahrettin Koca'nın kişisel imajını oluşturan ögelerin önem düzeyini belirlemeleri istenmiştir. Soruların seçenekleri ise, Hiç önemli değil (1), Önemli değil (2), Fikrim yok (3), Önemli (4) ve Çok önemli (5) şeklinde sıralanmıştır.

\section{Katılımcıların Bazı Özellikleri}

Araştırmaya katılan; 447 kişi cinsiyet olarak değerlendirildiğinde \% 44.3'ü erkek, \% 55.7'si kadın olduğu bulgusuna ulaşılmıştır. Elde edilen bu oranlar cinsiyet bakımından karşılaştırmanın yapılabileceği bir düzeyi ifade etmektedir. Katılımcların medeni durumuna bakıldığında \% 2.7'sinin evli, \% 97.3'ünün ise bekar olduğu ortaya çıkmaktadır. Katılımcıların \% 3.1'inin çocuk sahibi olduğu, \% 96.9'unun ise çocuk sahibi olmadığı sonucuna ulaşılmıştır. Katılımcıların yaş dağılımlarına bakıldığında; \% 90.8'i 15-25 yaş aralığında, \% 6.7'si 26-35 yaş aralığında, \% 1.1'i 36-45 yaş aralığında, \% 0.2'si 46-55 yaş aralığında, \% 0.7'si 56-65 yaş aralığında ve \% 0.4'ü 66 ve üzeri yaş grubunda yer almaktadır. Eğitim durumuna göre ankete katılanların \% 
98,2'i üniversite, \% 1.8'i lisansüstü öğrencisi olduklarını belirtmişlerdir. Çalışmanın üniversite öğrencilerine yönelik yapılması bu sonucu ortaya çıkarmaktadır. Katılımcıların \% 48.3'ü Radyo Televizyon ve Sinema, \% 20.1'i Yeni Medya, \% 17.4'ü Gazetecilik, \% 14.1'i ise Halkla İlişkiler ve Reklamcilık bölümünde öğrenci olduklarını belirtmişlerdir. Ankete katılan kişilerin ailelerinin aylık ortalama gelirlerini belirlemeye yönelik sorunun sonuçlarına bakıldığında ise; en düşük 3501- 4500 TL arası, en yüksek 2324 TL ve altı gelire sahip oldukları ortaya çıkmaktadır. Aylık gelir kategorize edildiğinde ise; katılımciların \% 37.6'sinın 2324 TL ve altı, \% 31.5'inin 2325- 3500 TL arası, \% 17.0'sının 4500 TL ve üzeri, \% 13.9'unun, 3501- 4500 TL arası gelir düzeyine sahip oldukları ortaya çıkmaktadır. Bu sonuçlar katılımcıların çoğunluğunun düşük gelir grubuna sahip kişiler olduğunu ifade etmektedir.

\section{Kişisel İmaj Hakkındaki Düşünceler}

Katılımcılarca kişisel imajin ne olarak algılandığını ortaya çıkarmak amacıyla "Kişisel imaj sizce nedir?" sorusu yöneltilmiştir. Cevaplara bakıldığında; \% 46.6'sı "Kişinin kişilik yansımasıdır"; \% 35.3'ü "Kişinin algılanma şeklidir"; \% 13.0'1 “Kişinin görüntüsüdür", \% 2.7'si “Fikrim yok”, \% 2.5'i ise "Kişinin sahte davranışlarıdır" cevabını vermiştir. Bu cevaba göre kişisel imaj önemli ölçüde "kişinin kişilik yansıması, kişinin algılanma şekli ve kişinin görüntüsü" olarak algilanmaktadır.

Çalışmada kişisel imajı oluşturan yedi faktör belirlenmiştir. Kişisel imaj oluşumunda bu faktörlerin önem düzeylerini belirlemek amaciyla "Kişisel imaj sizce aşağıdaki seçeneklerden en fazla hangisinden oluşmaktadır?" sorusu yöneltilmiştir. Soruyu cevaplayan katılımcıların \% 48.1'i kişinin beden dili, kullandığı renkler, yürüyüş ve oturuş biçimi gibi sözsüz iletişiminden”, \% 21.9'u “Kişinin karizma, özgüven, özsaygı gibi karakter özelliklerinden", \% 19.5'i "Kişinin birikim, deneyim, kişisel gelişim gibi yeterliliklerinden", \% 4.9'u "Kişinin görüntüsünden", \% 3.8'i “Kişinin sözlü iletişiminden", \% 1.3'ü “Kişinin yazma, sunum ve dinleme gibi diğer iletişim özelliklerinden", \% 0.4'ü de "Kişinin rahatlık ve huzur vermesinden" cevabını vermişlerdir. Bu cevaplara göre kişinin sözsüz iletişimini oluşturan beden dili, kullandığı renkler, yürüyüş ve oturuş biçimi gibi özellikler kişisel imajı oluşturan en önemli faktörler olarak görülmektedir. 
Tablo 1. Kişisel imajı oluşturan faktörlere verilen önem

\begin{tabular}{|c|c|c|}
\hline \multicolumn{3}{|l|}{ Kişisel imaj sizce en fazla hangisinden oluşmaktadır? } \\
\hline & Frekans & Yüzde \\
\hline Kişinin görüntüsünden & 22 & 4.9 \\
\hline Kişinin sözlü iletişiminden & 17 & 3.8 \\
\hline Kişinin beden dili, kullandığı renkler, yürüyüş ve oturuş gibi sözsüz iletişiminden & 215 & 48.1 \\
\hline Kişinin yazma, sunum ve dinleme gibi iletişim özelliklerinden & 6 & 1.3 \\
\hline Kişinin karizma, özgüven, özsaygı gibi karakter özelliklerinden & 98 & 21.9 \\
\hline Kişinin birikim, deneyim, kişisel gelişim gibi yeterliliklerinden & 87 & 19.5 \\
\hline Kişinin rahatllk ve huzur vermesinden & 2 & 0.4 \\
\hline Toplam & 447 & 100 \\
\hline
\end{tabular}

\section{Sağlık Bakanı Fahrettin Koca'nın Kişisel İmajı}

Sağlık Bakanı Fahrettin Koca'nın katılımcılar tarafından tanınırlığını belirlemek amacıyla "Covid 19 Süreci öncesi Sağlık Bakanı Fahrettin Koca'yı tanıyor muydunuz?" sorusu yöneltilmiştir. Cevaplara göre katılımcıların \% 50.6'sı hayır, \% 49.4'ü ise evet cevabını vermişlerdir.

Tablo 2. Covid 19 süreci öncesi Sağlık Bakanı Fahrettin Koca'nın tanınırlı̆̆ı

Covid 19 Süreci öncesi Sağlık Bakanı Fahrettin Koca'yı tanıyor muydunuz?

\begin{tabular}{lcl}
\hline & Frekans & Yüzde \\
\hline Evet & 221 & 49.4 \\
\hline Hayır & 226 & 50.6 \\
\hline Toplam & $\mathbf{4 4 7}$ & $\mathbf{1 0 0}$ \\
\hline
\end{tabular}

Sağlık Bakanı Fahrettin Koca'nın katılımcılar üzerindeki imajını ölçmek amacıyla "Sağlık Bakanı Fahrettin Koca'nın kişisel imajı nasıldır?" sorusu sorulmuştur. Cevapların \% 89.3'ü olumlu, \% 2.7'si olumsuz ve \% 8.1'i de fikrim yok cevabını vermişlerdir. Bu sonuçlara göre Sağlık Bakanı Fahrettin Koca'nın katılımcılar nezdinde imajının büyük oranda olumlu olduğu bulgusuna ulaşılmışır.

Tablo 3. Sağlık Bakanı Fahrettin Koca'nın imajı

\begin{tabular}{lll}
\hline Sağlık Bakanı Fahrettin Koca'nın kişisel imajı nasıldır? & & \\
\hline & Frekans & Yüzde \\
\hline Olumlu & 399 & 89.3 \\
\hline Olumsuz & 12 & 2.7 \\
\hline Fikrim Yok & 36 & 8.1 \\
\hline Toplam & $\mathbf{4 4 7}$ & $\mathbf{1 0 0}$ \\
\hline
\end{tabular}

Sağlık Bakanı Fahrettin Koca'nın açk bir iletişim şeklini kullanıp kullanmadığının belirlenmesi amacıyla “COVID 19 Sürecinde Sağlık Bakanı Fahrettin Koca'nın bu süreci şeffaf bir şekilde yönettiğini düşünüyor musu- 
nuz?" sorusu yöneltilmiştir. Verilen cevapların \% 72.7'si evet, \% 15.2'si hayır ve \% 12.1'i de fikrim yok şeklindedir.

Tablo 4. Sağlık Bakanı Fahrettin Koca'nın Şeffafliğı

\begin{tabular}{lll}
\hline COViD 19 Sürecinde Sağlık Bakanı Fahrettin Koca'nın bu süreci şeffaf bir şekilde yönettiğini düšünüyor musunuz? \\
\hline & Frekans & Yüzde \\
\hline Evet & 325 & 72.7 \\
\hline Hayır & 68 & 15.2 \\
\hline Fikrim Yok & 54 & 12.1 \\
\hline Toplam & $\mathbf{4 4 7}$ & $\mathbf{1 0 0}$ \\
\hline
\end{tabular}

Sağlık Bakanı Fahrettin Koca'nın güvenilirliğinin belirlenmesi amacıyla katılımclara "Sağlık Bakanı Fahrettin Koca'nın Covid 19 sürecindeki gelişmelerle ilgili açıklamaları inandırıcı geliyor mu ?" sorusu yöneltilmiştir. Katılımcların 73.2'si evet, \% 16.8'i hayır ve \% 10.1'i de fikrim yok şeklinde cevaplamışlardır. Bu dağılıma göre Sağlık Bakanı Fahrettin Koca'nın güvenilirliğinin büyük ölçüde olumlu olduğu sonucu elde edilmiştir.

Tablo 5. Sağlık Bakanı Fahrettin Koca'nın İnandırıcılı̆̆

\begin{tabular}{lll}
\hline Sağlık Bakanı Fahrettin Koca'nın Covid 19 Sürecindeki gelişmelerle ilgili açılamaları inandırıcı geliyor mu ? \\
\hline & Frekans & Yüzde \\
\hline Evet & 325 & 72.7 \\
\hline Hayır & 68 & 15.2 \\
\hline Fikrim Yok & 54 & 12.1 \\
\hline Total & $\mathbf{4 4 7}$ & $\mathbf{1 0 0}$ \\
\hline
\end{tabular}

Sağlık Bakanı Fahrettin Koca'nın katılımcılar nezdindeki imajını tanımlamak amaciyla "Fahrettin Koca'nın sizdeki imajını bir kelimeyle ifade edecek olsanız nasıl tanımlarsınız?" sorusu açık uçlu olarak sorulmuştur. Ortaya çıkan cevaplar kategorize edilerek frekans analizine tabi tutulduğunda, katılımcıların \% 19.0'1 dürüst, güvenilir, şeffaflık; \% 11.9'u babacan, samimi, düşünceli; \% 5,6'i çalışkan, çabalayıcl; \% 2,7'si güçlü olarak ifade etmişlerdir. Katılımcılar en az düzeyde de başarılı (\% 1.8) ve bilgili, yeterli, yetkili (\% 1.6) imajını ifade etmişlerdir. Sonuçlara bakıldığında Sağlık Bakanı Fahrettin Koca, katılımclara göre en fazla samimi, babacan, dürüst, güvenilir, yeterli, başarılı olarak tanımlanmaktadır. 
Tablo 6. Sağlık Bakanı Fahrettin Koca'nın İmajı

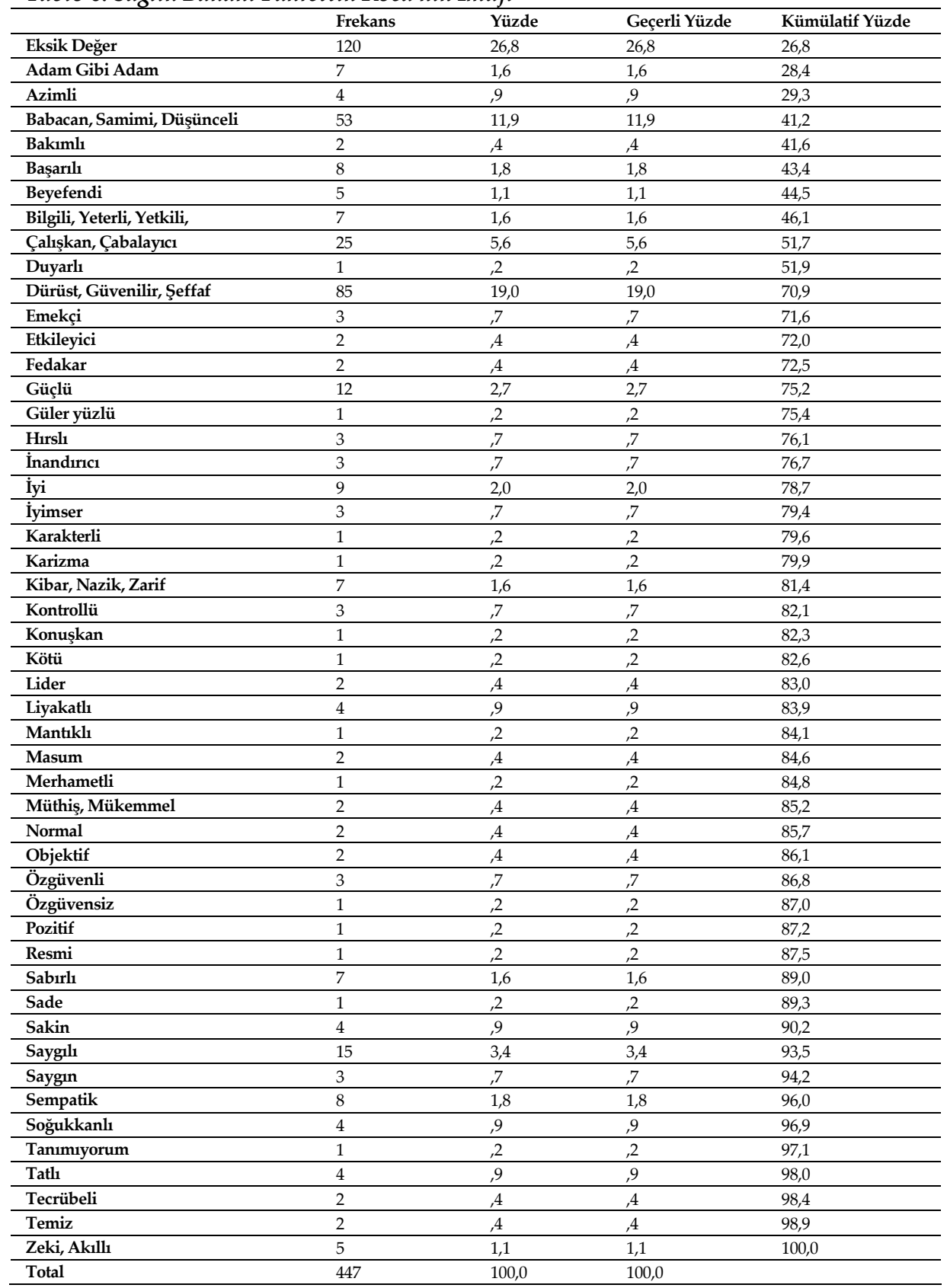




\section{Sağlık Bakanı Fahrettin Koca'nın Kişisel İmajına Etki Eden Faktörlerin Genel Önem Düzeyleri}

Sağlık Bakanı Fahrettin Koca'nın, her bir faktör için hesaplanan ve aritmetik ortalamaya dayanan indeks kullanılmıştır. Sağlık Bakanı Fahrettin Koca'nın kişisel imajinı etkileyen faktörlerin her birinin toplam aritmetik ortalamaları analiz edildiğinde anketi cevaplayan katılımcıların en çok önem verdiğ $i$ değişken, aritmetik ortalaması en yüksek olanıdır.

Tablo 7. Görüntü Faktörüyle İlgili Maddelerin Betimleyici İstatistik Sonuçlan

\begin{tabular}{llllll}
\hline MADDELER/GÖRÜNTÜ & N & Min. & Maks. & A.Ortalama & S.Sapma \\
\hline Genç Olması & 447 & 1,00 & 5,00 & 2,0358 & 1,15155 \\
\hline Orta boylu olması & 447 & 1,00 & 4,00 & 1,5951 &, 77764 \\
\hline Kilolu olmaması & 447 & 1,00 & 5,00 & 1,8479 & 1,05207 \\
\hline Saçlarının dökülmemiş olması & 447 & 1,00 & 5,00 & 1,7964 & 1,02489 \\
\hline Biyılı olması & 447 & 1,00 & 5,00 & 1,7204 &, 88845 \\
\hline Giyim Tarzı & 447 & 1,00 & 5,00 & 3,2528 & 1,46134 \\
\hline Kibar Olması & 447 & 1,00 & 5,00 & 4,2461 & 1,04916 \\
\hline
\end{tabular}

Buna göre katılımcıların Sağlık Bakanı Fahrettin Koca'nın kişisel imajına etki eden görüntü faktörünü oluşturan değişkenler arasında en yüksek ortalamayı "Kibar olması" (A.O.=4.24) almaktadır. Bunu "Giyim Tarzı" (A.O.=3.25) ve "Kravat Kullanması" (A.O.=3.21) izlemektedir. "Orta Boylu Olması" (A.O.=1.59) ve "Bıyıklı Olması" (A.O.=1.72) gibi unsurları katılımcıların daha az önemsedikleri ortaya çıkmaktadır. Genel olarak değerlendirildiğinde; Sağlık Bakanı Fahrettin Koca'nın kişisel imajını oluşturan görüntü özellikleri içerisinde "Kibar Olması" en önemli özelliği konumundayken; "Orta Boylu Olması" ise katılımclar tarafından en az önem verilen özelliği olarak görülmektedir.

Tablo 8. Sözlü İletişim Faktörüyle İlgili Maddelerin Betimleyici İstatistik Sonuçlan

\begin{tabular}{llllll}
\hline MADDELER/SÖZLÜ İLETIŞiM & N & Min. & Maks. & A.Ortalama & S.Sapma \\
\hline Sesin Tonu & 447 & 1,00 & 5,00 & 3,9821 & 1,12239 \\
\hline Sesin Şiddeti & 447 & 1,00 & 5,00 & 3,9597 & 1,16495 \\
\hline Konuşmasındaki kelime çeşitliliği & 447 & 1,00 & 5,00 & 4,1924 & 1,07087 \\
\hline Konuşma Tarzı & 447 & 1,00 & 5,00 & 4,2998 & 1,01539 \\
\hline
\end{tabular}

Katılımcıların Sağlık Bakanı Fahrettin Koca'nın kişisel imajina etki eden sözlü iletişim faktörünü oluşturan değişkenler arasında en yüksek ortalamayı "Konuşma Tarzı" (A.O.=4.29) almaktadır. Bunu "Konuşmasındaki Kelime Çeşitliliği" (A.O.=4.19) ve "Sesinin Tonu" (A.O.=3.98) izlemektedir. 
"Sesinin Şiddeti" (A.O.=3.95) unsuru ise katılımcilar tarafından daha az önemsenmektedir. Bu sonuçlar değerlendirildiğinde; Sağlık Bakanı Fahrettin Koca'nın kişisel imajını oluşturan sözlü iletişim özellikleri içerisinde "konuşma tarzı" en önemli özelliği konumundayken; "sesinin şiddeti" en az önem verilen özelliği olarak ön plana çıkmaktadır.

Tablo 9. Sözsüz İletişim Faktörüyle İlgili Maddelerin Betimleyici İstatistik Sonuçları

\begin{tabular}{llllll}
\hline MADDELER/SÖZSÜZ İLETişiM & N & Min. & Max. & A.Ortalama & S.Sapma \\
\hline Konuşurken mimiklerin kullanılması & 447 & 1,00 & 5,00 & 4,1723 & 1,03929 \\
\hline Konuşurken Ellerin Kolların Kullanılması & 447 & 1,00 & 5,00 & 4,0738 & 1,07829 \\
\hline Giyim ve Aksesuarlarında Belirli Renklerin Kullanılması & 447 & 1,00 & 5,00 & 3,2260 & 1,31068 \\
\hline Vatandaşla Yakın Temasta Bulunması & 447 & 1,00 & 5,00 & 3,6644 & 1,27732 \\
\hline Yürüyüş Şekli & 447 & 1,00 & 5,00 & 3,0582 & 1,34305 \\
\hline Oturuş Biçimi & 447 & 1,00 & 5,00 & 3,5078 & 1,31371 \\
\hline Zaman Kullanımı & 447 & 1,00 & 5,00 & 3,8971 & 1,12977 \\
\hline Mekan Kullanımı & 447 & 1,00 & 5,00 & 3,6376 & 1,19537 \\
\hline
\end{tabular}

Sağlık Bakanı Fahrettin Koca'nın kişisel imajına etki eden sözsüz iletişim faktörünü oluşturan değişkenler arasında en yüksek ortalamayı "Konuşurken Mimiklerin Kullanılması" (A.O.=4.17) maddesi almaktadır. Bu maddeyi "Konuşurken Ellerin Kolların Kullanılması" (A.O.=4.07) ve "Zaman Kullanımı" (A.O.=3.89) izlemektedir. Bu özellikler, kişisel imajın sözsüz iletişim boyutu içerisinde büyük öneme sahip olduğunun bir göstergesi olarak ortaya çıkmaktadır. "Yürüyüş Şekli" (A.O.=3.05) ve "Giyim ve Aksesuarlarında Belirli Renkleri Kullanması" (A.O.=3.22) maddelerini katılımcıların daha az önemsedikleri görülmektedir. Elde edilen bulgular doğrultusunda; Sağlık Bakanı Fahrettin Koca'nın kişisel imajını oluşturan sözsüz iletişim özellikleri içerisinde "Konuşurken Mimiklerin Kullanılması" en önemli özelliği iken; en az önem verilen özelliği ise "Yürüyüş Şekli" olarak görülmektedir.

Tablo 10. Diğer İletişim Faktörüyle İlgili Maddelerin Betimleyici İstatistik Sonuçlan

\begin{tabular}{llllll}
\hline MADDELER/DIĞER İLETIŞIM & $\mathbf{N}$ & Min. & Maks. & A.Ortalama & S.Sapma \\
\hline Twitter'da yazım becerisi & 447 & 1,00 & 5,00 & 3,7472 & 1,30232 \\
\hline Sunum Becerisi & 447 & 1,00 & 5,00 & 4,1096 & 1,08561 \\
\hline Dinleme Becerisi & 447 & 1,00 & 5,00 & 4,1477 & 1,03985 \\
\hline
\end{tabular}

Sağlık Bakanı Fahrettin Koca'nın kişisel imajina etki eden "diğer iletişim" faktörünü oluşturan değişkenler arasında en yüksek ortalamayı "Dinleme Becerisi" (A.O.=4.14) alırken, dinleme becerisini "Sunum Becerisi" (A.O.=4.10) izlemektedir. "Twitterde Yazım Becerisi" (A.O.=3.74) ise, kat1lımcıların daha az önemsedikleri maddeyi oluşturmaktadır. Çıkan sonuçla- 
ra göre değerlendirildiğinde; Sağlık Bakanı Fahrettin Koca'nın kişisel imajını oluşturan diğer iletişim özellikleri içerisinde "dinleme becerisi" en önemli yeri alırken; önem seviyesi en düşük özelliği ise "twitterde yazım becerisi" olarak değerlendirilmektedir.

Tablo 11.Karakter Faktörüyle İlgili Maddelerin Betimleyici İstatistik Sonuçlan

\begin{tabular}{llllll}
\hline MADDELER/KARAKTER & N & Min. & Maks. & A.Ortalama & S.Sapma \\
\hline Karizması & 447 & 1,00 & 5,00 & 3,3065 & 1,35181 \\
\hline Özgüveni & 447 & 1,00 & 5,00 & 4,1342 & 1,11446 \\
\hline Özsaygısı & 447 & 1,00 & 5,00 & 4,1566 & 1,12357 \\
\hline Dindarlığ1 & 447 & 1,00 & 5,00 & 2,1588 & 1,24176 \\
\hline
\end{tabular}

Katılımcıların Sağlık Bakanı Fahrettin Koca'nın kişisel imajına etki eden "karakter" faktörünü oluşturan değişkenler arasında en yüksek ortalamayı "Özsaygısı" (A.O.=4.15) maddesi meydana getirmektedir. Bu maddeyi "Özgüveni" (A.O.=4.13) ve "Karizması" (A.O.=3.30) izlemektedir. Özsayg1, özgüven ve karizma unsurlarının kişisel imajın karakter boyutu içerisinde önemli bir yere sahip olduğu ortaya çıkan sonuçlar arasındadır. "Dindarlığı" (A.O.=2.15) ise katılımclların en az önemsedikleri maddeyi oluşturmaktadır. Çıkan bulgular etrafında değerlendirildiğinde; "Özsaygısı" Sağlık Bakanı Fahrettin Koca'nın kişisel imajını oluşturan karakter özellikleri içerisinde önem düzeyi en yüksek özelliği iken, "dindarlığı" ise en az önem gören özelliğidir.

Tablo 12. Yeterlilik Faktörüyle İlgili Maddelerin Betimleyici İstatistik Sonuçlan

\begin{tabular}{llllll}
\hline MADDELER/YETERLILIKK & N & Min. & Maks. & A.Ortalama & S.Sapma \\
\hline Birikimi & 447 & 1,00 & 5,00 & 3,4139 & 1,54051 \\
\hline Potansiyeli & 447 & 1,00 & 5,00 & 4,0671 & 1,13642 \\
\hline Kişisel Gelişimi & 447 & 1,00 & 5,00 & 4,1812 & 1,06758 \\
\hline Deneyimi & 447 & 1,00 & 5,00 & 4,2438 & 1,04218 \\
\hline Göze Çarparlığı & 447 & 1,00 & 5,00 & 3,3714 & 1,29014 \\
\hline
\end{tabular}

Sağlık Bakanı Fahrettin Koca'nın kişisel imajina etki eden yeterlilik faktörünü oluşturan değişkenler arasında en yüksek ortalamayı "Deneyimi" (A.O.=4.24) oluşturmaktadır. Bunu "Kişisel Gelişimi" (A.O.=4.18) ve "Potansiyeli" (A.O.=4.06) izlemektedir. "Birikimi" (A.O.=3.41) ve "Göze Çarparlı̆̆ı" (A.O.=3.37) ise katılımcların daha az önemsedikleri maddeyi oluşturmaktadır. Sonuç olarak bakıldığında; Sağlık Bakanı Fahrettin Koca'nın kişisel imajını oluşturan yeterlilik özellikleri içerisinde "deneyimi" en önemli 
özelliği iken; "göze çarparlığı" en az önem verilen özelliği olarak değerlendirilmektedir.

Tablo 13.Davranış Tavır Faktörüyle İlgili Maddelerin Betimleyici İstatistik Sonuçlar

\begin{tabular}{llllll}
\hline MADDELER/TAVIR & N & Min. & Maks. & A.Ortalama & S.Sapma \\
\hline Tavır ve Davranışı & 447 & 1,00 & 5,00 & 4,1902 & 1,07022 \\
\hline Rahatlığı & 447 & 1,00 & 5,00 & 3,7517 & 1,17469 \\
\hline Huzurluluğu & 447 & 1,00 & 5,00 & 3,8322 & 1,16605 \\
\hline Samimiyeti & 447 & 1,00 & 5,00 & 4,1834 & 1,06615 \\
\hline Baba Olması (Çocuğunun Olması) & 447 & 1,00 & 5,00 & 2,3714 & 1,27088 \\
\hline Evli Olması & 447 & 1,00 & 5,00 & 2,0872 & 1,17102 \\
\hline
\end{tabular}

Katılımcılar Sağlık Bakanı Fahrettin Koca'nın kişisel imajına etki eden davranış tavır faktörü değişkenlerinden en yüksek ortalamayı "Tavır ve Davranışı" (A.O.=4.19) oluştururken bunu, Samimiyeti" (A.O.=4.18) ile "Huzurluluğu" (A.O.=3.83) izlemektedir. "Evli Olması" (A.O.=2.08) ve "Baba Olması" (A.O.=2.37) gibi maddeler ise katılımclların daha az önemsedikleri maddeleri oluşturmaktadır. Sonuç olarak bakıldığında; Sağlık Bakanı Fahrettin Koca'nın kişisel imajını oluşturan davranış tavır özellikleri içerisinde "Tavır ve Davranış" en önemli özelliği iken; "Evli Olması" en az önem verilen özelliği olarak ifade edilmektedir.

\section{Sağlık Bakanı Fahrettin Koca'nın Kişisel İmajını Oluşturan Faktörler Arasındaki İlişki}

Kişisel imaj faktörleri arasındaki ilişkinin şiddetini tanımlamak bakımından korelasyon analizi sonuçlarına bakıldığında; görüntü faktörü ile sözlü iletişim faktörü $(\mathrm{r}=.42, \mathrm{p}<.01)$, görüntü faktörü ile sözsüz iletişim faktörü $(\mathrm{r}=.50$, $\mathrm{p}<.01)$, görüntü faktörü ile karakter faktörü $(\mathrm{r}=.43, \mathrm{p}<.01)$ ve yine görüntü faktörü ile davranış tavır faktörü $(\mathrm{r}=.38, \mathrm{p}<.01)$ arasında orta düzeyde anlamlı bir ilişki vardır. Kişisel imajda görüntü faktörünü önemli gören katılımcllar, sözlü iletişim, sözsüz iletişim, karakter ve davranış tavır faktörlerini de önemli görmektedirler. Yine ayn tablo incelendiğinde görüntü faktörü ile diğer iletişim faktörü $(\mathrm{r}=.32$, $\mathrm{p}<.01)$ ve görüntü faktörü ile yeterlilik faktörü $(\mathrm{r}=.31, \mathrm{p}<.01)$ arasında da zayıf düzeyde ilişkinin olduğu anlaşılmaktadir. 
Tablo 14. Faktörler Arasındaki İlişki Düzeyini Gösteren Korelasyon Tablosu

\begin{tabular}{|c|c|c|c|c|c|c|c|}
\hline & Görüntü & $\begin{array}{l}\text { Sözlü } \\
\text { İletişim }\end{array}$ & $\begin{array}{l}\text { Sözsüz } \\
\text { İletişim }\end{array}$ & $\begin{array}{l}\text { Diğer } \\
\text { İletişimler }\end{array}$ & Karakter & Yeterlilik & Tavir \\
\hline & 1 & $424^{* *}$ &, $506^{*}$ &, $325^{*}$ & $430^{* \prime \prime}$ & $319^{* *}$ & $387^{* \prime \prime}$ \\
\hline Görüntü & & ,000 &, 000 &, 000 &, 000 &, 000 &, 000 \\
\hline \multirow[t]{2}{*}{$\mathbf{N}$} & 447 & 447 & 447 & 447 & 447 & 447 & 447 \\
\hline &, $424^{*}$ & 1 & ,781* &, $749^{*}$ & $660^{* *}$ & ,764 & $652^{*}$ \\
\hline Sözlü İletişim &, 000 & & ,000 &, 000 &, 000 &, 000 & ,000 \\
\hline \multirow[t]{2}{*}{$\mathbf{N}$} & 447 & 447 & 447 & 447 & 447 & 447 & 447 \\
\hline &, $506^{*}$ &, $781^{*}$ & 1 & ,762* & ,724" & $718^{*+}$ & ,706* \\
\hline Sözsüz İletişim &, 000 & ,000 & & ,000 & ,000 & , 000 & , 000 \\
\hline \multirow[t]{2}{*}{$\mathbf{N}$} & 447 & 447 & 447 & 447 & 447 & 447 & 447 \\
\hline & $325^{*}$ & ,749" & ,762" & 1 & ,701* & ,743" & ,709* \\
\hline Diğer İletişimler &, 000 & 000 & ,000 & & ,000 & ,000 & ,000 \\
\hline \multirow[t]{2}{*}{$\mathbf{N}$} & 447 & 447 & 447 & 447 & 447 & 447 & 447 \\
\hline & $430^{*}$ &, $660^{*}$ & ,724* & ,701* & 1 & ,747" & ,735* \\
\hline Karakter &, 000 &, 000 &, 000 &, 000 & &, 000 &, 000 \\
\hline \multirow[t]{2}{*}{$\mathbf{N}$} & 447 & 447 & 447 & 447 & 447 & 447 & 447 \\
\hline &, $319^{*}$ &, $764^{* *}$ & ,718 & ,743* & ,747" & 1 & ,744* \\
\hline Yeterlilik &, 000 & 000 & ,000 & ,000 & ,000 & & , 000 \\
\hline \multirow[t]{2}{*}{$\mathbf{N}$} & 447 & 447 & 447 & 447 & 447 & 447 & 447 \\
\hline &, $387^{*}$ & ,652" & ,706" & ,709* & ,735" & ,744" & 1 \\
\hline Tavir &, 000 &, 000 &, 000 &, 000 &, 000 &, 000 & \\
\hline $\mathbf{N}$ & 447 & 447 & 447 & 447 & 447 & 447 & 447 \\
\hline
\end{tabular}

**. Correlation is significant at the 0.01 level (2-tailed).

(Not: 0-350 arası zayıf, 351-700 arası orta, 701-1000 arası güçlü ilişkinin varlığını gösteren değerlerdir.)

Sözlü iletişim faktörü ile karakter faktörü ( $\mathrm{r}=.66$, $\mathrm{p}<.01)$, ve davranış tavır faktörü ( $\mathrm{r}=.65, \mathrm{p}<.01)$ arasında orta düzeyde pozitif anlamlı bir ilişki söz konusudur. Sözlü iletişim faktörü ile sözsüz iletişim faktörü $(\mathrm{r}=.78, \mathrm{p}<.01)$, diğer iletişim faktörü $(r=.74, \mathrm{p}<.01)$ ve yeterlilik faktörü $(\mathrm{r}=.76, \mathrm{p}<.01)$ arasında yüksek düzeyde pozitif anlamlı bir ilişki söz konusudur. Katılımcların sözlü iletişim faktörünün yanında sözsüz iletişim, diğer iletişim, karakter ve yeterliliğe de önem verdikleri görülmektedir. Sözsüz iletişim faktörü ile diğer iletişim faktörü $(\mathrm{r}=.76, \mathrm{p}<.01)$, karakter faktörü $(\mathrm{r}=.72$, $\mathrm{p}<.01)$, yeterlilik faktörü $(\mathrm{r}=.71, \mathrm{p}<.01)$ ve davranış tavır faktörü $(\mathrm{r}=.70, \mathrm{p}<.01)$ arasında pozitif yüksek düzeyde ilişki vardır. Buna göre sözsüz iletişim faktörünün önemli olduğunu düşünenler aynı zamanda diğer iletişim, karakter, yeterlilik ve davranış tavır faktörünün de fazlasıyla önemli olduğunu düşünmektedirler. Diğer iletişim faktörüne önem veren deneklerin de karakter faktörüne $(\mathrm{r}=.70, \mathrm{p}<.01)$, yeterlilik faktörüne $(\mathrm{r}=.74, \mathrm{p}<.01)$ ve davranış tavır 
faktörüne de $(\mathrm{r}=.70, \mathrm{p}<.01)$ pozitif yüksek düzeyde önem verdikleri tespit edilmiştir.

Karakter faktörü ile yeterlilik faktörü $(\mathrm{r}=.74, \mathrm{p}<.01)$ arasında ve karakter faktörü ile davranış tavır faktörü $(\mathrm{r}=.73, \mathrm{p}<.01)$ arasında güçlü düzeyde pozitif anlamlı ilişki vardır. Yani karakter faktörüne çok önem veren denekler aynı zamanda davranış tavır faktörüne de çok büyük düzeyde önem vermektedirler.

Yeterlilik faktörü ile davranış tavır faktörü $(\mathrm{r}=.74, \mathrm{p}<.01)$ arasında da yüksek düzeyde pozitif anlamlı ilişki bulunmaktadır. Bunun anlamı ise; yeterlilik faktörüne önem veren deneklerin davranış tavır faktörüne de yüksek düzeyde önem vermeleridir.

\section{Cinsiyete Göre Faktörlere Verilen Önem Düzeyleri}

Cinsiyete göre faktörler arasında farklılık olup olmadığını ortaya koymak amacıyla t-testi yapıldığında Sözsüz İletişim ( $t=2,67$; sd=445; $p<.05)$, Diğer İletişim ( $\mathrm{t}=2,04 ; \mathrm{sd}=445 ; \mathrm{p}<.05)$ faktörüne verilen önem anlamlı farklılık göstermektedir.

\section{Medeni Duruma Göre Faktörlere Verilen Önem Düzeyleri}

Katılımcıların medeni durumlarına göre imaj faktörleri arasında anlamlı bir farklılık olmadığı sonucuna ulaşılmıştır.

\section{Çocuk Sahibi Olup Olmadıklarna Göre Faktörlere Verilen Önem Düzeyleri}

Çocuk sahibi olup olmadıklarına göre imaj faktörleri arasında farklılık olup olmadığını ortaya koymak amacıyla $\mathrm{t}$-testi yapıldığında Sözlü İletişim ( $\mathrm{t=-}$ 2,15; sd=445; $p<.05)$ Sözsüz İletişim ( $t=-2,91 ; s d=445 ; p<.05)$, Diğer İletişim ( $t=-$ $3.81 ; \mathrm{sd}=445 ; \mathrm{p}<.05)$ ve Tavır ( $\mathrm{t}=-2,50 ; \mathrm{sd}=445 ; \mathrm{p}<.05)$ faktörüne verilen önem anlamlı farklılık göstermektedir.

İmaj faktörleriyle yaş, eğitim, gelir düzeyi ve bölüm gibi bağımsız değişkenler arasındaki ilişkiyi ortaya koymak açısından Anova testi yapıldığında ise eğitim durumunda ve yaş değişkeninde üçten az grup olduğu için PostHoc testlerinin yapılması da mümkün olmamıştır. 


\section{Okuduklarn Bölüme Göre Faktörlere Verilen Önem Düzeyleri}

Katılımcıların okudukları bölüm ile imaj faktörleri arasında Görüntü faktörü $(\mathrm{F}=6,539 ; 00, \mathrm{p}<0,05)$, Sözlü İletişim $(\mathrm{F}=5,349 ; 01, \mathrm{p}<0,05)$, Sözsüz İletişim $(\mathrm{F}=6,951 ; 00, \quad \mathrm{p}<0,05)$, Diğer İletişim $(\mathrm{F}=3,653 ; 13, \quad \mathrm{p}<0,05)$, Yeterlilik $(\mathrm{F}=2,833 ; 38, \mathrm{p}<0,05)$ faktörlerine verilen önem anlamlı bir farklılık göstermektedir. Görüntü, Sözlü İletişim faktörlerinin varyansları homojen olduğundan bakılan Tukey Testi sonucunda, Halkla İlişkiler ve Reklamcilık bölümündeki katılımcılar ve Radyo Televizyon ve Sinema bölümündeki kat1lımcılar, Gazetecilik bölümündeki katılımclara oranla görüntü ve sözlü iletişim faktörlerine daha fazla önem vermektedirler.

Sözsüz İletişim, Diğer İletişim, Yeterlilik faktörlerinin varyansları homojen olmadığından bakılan Tamhane Testi sonucunda, Halkla İlişkiler ve Reklamcllı bölümünde okuyan katılımcılar ve Radyo Televizyon ve Sinema bölümünde okuyan katılımcllar, Gazetecilik bölümünde okuyan katılımcllara oranla Sözsüz İletişim, Diğer İletişim ve Yeterlilik faktörlerine daha fazla önem vermektedirler. Karakter Faktörü ve Tavır Faktörü arasında anlamlı bir farklılık olmadığı tespit edilmiştir.

\section{Gelirlerine Göre Faktörlere Verilen Önem Düzeyleri}

Katılımcların gelirleri ile imaj faktörleri arasında Sözsüz İletişim ( $\mathrm{F}=2,688 ; 46$, $\mathrm{p}<0,05)$, Sözlü İletişim $(\mathrm{F}=3,402 ; 18$, $\mathrm{p}<0,05)$, Tavır $(\mathrm{F}=4,072 ; 07$, $\mathrm{p}<0,05)$, Karakter $(\mathrm{F}=7,014 ; 00, \mathrm{p}<0,05)$, Yeterlilik $(\mathrm{F}=6,371 ; 00, \mathrm{p}<0,05)$ faktörlerine verilen önem anlamlı bir farklılık göstermektedir.

Sözsüz İletişim, Sözlü İletişim, Karakter, Yeterlilik faktörlerinin varyansları homojen olduğundan bakılan Tukey Testi sonucunda, 3501 TL ve 4500 TL arasında gelire sahip katılımclar 4501 TL ve üzeri gelire sahip katılımc1lara oranla sözlü ve sözsüz iletişim faktörlerine daha fazla önem vermektedirler. 3501 TL ve 4500 TL arasında gelire sahip katılımclar diğer gelir düzeylerine sahip katılımcllara oranla Yeterlilik faktörüne daha fazla önem vermektedirler. 4501 TL ve üzeri gelire sahip katılımcılar ise diğer gelir düzeyine sahip katılımcılara oranla Karakter faktörüne daha az önem vermektedirler.

Tavır faktörünün varyansları homojen olmadığından bakılan Tamhane Testi sonucunda, 4501 TL ve üzeri gelire sahip katılımcllar, 2325 TL ve 3500 TL arasi gelire sahip olan ve 3501 TL ve 4500 TL arası gelire sahip olan kat1- 
lımcılara oranla Tavır faktörüne daha az önem verdikleri sonucuna ulaşılmiştır.

\section{Sonuç ve Öneriler}

Geçmişten günümüze uzanan zaman diliminde imaj, itibar, güvenilirlik, saygınlık gibi kavramlar hiçbir zaman önemini yitirmemiş aksine önem kazanmıştır. Özellikle günümüzde dijital dünyanın giderek daha fazla tüketilmesi, ve bu mecralardaki bilgi kirlilikleri yukarıda bahsedilen kavramların yönetimini de zorlaştırmıştır. Ancak doğruluk, şeffaflık, güçlü bir sözlü iletişim, beden hareketlerinin doğru kullanımı, sözcük seçimi, kılık kıyafetin ve kullanılan aksesuarların yerinde kullanımı imaja doğrudan etki ettiği ve imaj, itibar, saygınlık gibi kavramları güçlendirdiği görülmektedir. İmajın sadece dış görünüş olmadığ ses tonundan, sözcük seçimine, hitap tarzından, vurgu ve tonlamaya, şeffaflıktan alanı hakkında yeterliliğe kadar olan kapsamlı bir süreç olduğu ortaya çıkmaktadır. Dolayısıyla özellikle kamuoyu önünde devamlı suretle bulunan politikacılar, sanatçlar, sivil toplum örgütü temsilcileri, kanaat önderleri kendi fikir ve görünüşlerinin halkta daha fazla karşılık bulması adına imaj çalışmalarına çok daha fazla önem vermeleri gerektiğinin farkındadırlar.

İmajın çok önemli olduğu günümüzde imaj yönetimine de daha fazla önem vermek kaçınılmazdır. Toplum tarafından algılanma şekli olarak karşımıza çıkan imaj çalışmalarını ölçmek ve günümüzde dünyayı etkisi altına alan salgın hastalığın Türkiye ayağını yöneten Sağlık Bakanı Fahrettin Koca'nın kişisel imajını ortaya koymak amacıyla Uşak Üniversitesi İletişim Fakültesi Öğrencileri üzerinde yapılan araştırmaya göre:

- Kişisel imaj, katılımcılar tarafından "kişinin kişilik yansıması, kişinin algılanma şekli" olarak algilanmaktadır.

- Kişinin sözsüz iletişimini oluşturan beden dili, kullandığı renkler, yürüyüş ve oturuş biçimi gibi özellikleri, kişisel imajı oluşturan en önemli unsurlar arasında görülmektedir.

- Sağlık Bakanı Fahrettin Koca'nın halk üzerindeki imajı büyük oranda olumludur ve katılımcllar tarafından sempatik, babacan, samimi, güvenilir ve dürüst kişilik olarak tanımlanmaktadır. 
- Sağlık Bakanı Fahrettin Koca'nın kişisel imajını oluşturan en önemli özellikleri "kibar olması", "konuşma tarzi", "el ve kol hareketleri", "dinleme becerisi", "deneyimi" ve "samimiyeti" dir.

- Kişisel imaj oluşumunda kişinin sözlü iletişim ve sözsüz iletişim şekline önem verenler; kişinin diğer iletişim, karakter, yeterlilik ve davranış tavır özelliklerine de önem vermektedirler.

- Kişisel imaj oluşumunda kişinin diğer iletişim şekline önem verenler; kişinin karakter özelliklerine, yeterlilik özelliklerine ve davranış tavır özelliklerine de yüksek düzeyde önem vermektedirler.

- Kişisel imajda kadınlar erkeklere göre kişilerin sözsüz ve diğer iletişim özelliklerine daha fazla dikkat etmektedirler.

- Kişisel imajda gelir düzeyi yüksek olan katılımcıların karakter ve tavır faktörlerine daha az önem vermektedirler.

- Medeni durum kişisel imaja verilen önemi etkilememektedir.

Sonuç olarak; Sağlık Bakanı Fahrettin Koca'nın kişisel imajı katılımcılar açısından önemli ölçüde olumludur. Bu olumlu kanaati oluşturan en önemli özellikler ise; samimiyeti, konuşma tarzı, deneyimi, el ve kol hareketleridir.

Yapılan bu çalışmanın sonucunda ise çalışmanın tüm Türkiye de yapılması Sağlık Bakanı Fahrettin Koca'nın kişisel imajını ortaya koymak açısindan daha genel verilerin elde edilmesine neden olacaktır. 
EXTENDED ABSTRACT

\title{
A Field Study To Determine Personal Image Elements Of Fahrettin Koca, Minister Of Health Of The Republic Of Turkey, During The Covid-19 Process
}

\author{
Zülfiye Acar Şentürk - Ali Mutlu \\ Uşak University
}

Today, it is seen that politicians, artists, representatives of nongovernmental organizations, and opinion leaders, who are continuously in front of the public, attach great importance to image work. The verbal and non-verbal communication, writing, presenting, listening, characters, competencies, behaviors, actions, and discourses of these actors attaching great importance to image studies to increase the influence of their speeches, to enhance the credibility of their attitudes, and to find more supports in public, constitute their images. Image studies carried out by the professionals in the periods of election campaigns and crisis managements particularly, are conducted intensely to find more answers in the society. In such a crisis period, during the pandemic, Health Minister Prof. Dr. Fahrettin Koca announced the crucial measures and the developments related to the epidemic both through the mass media and new media tools and informed the public by holding press conferences regularly.

In order to reveal to which of the features composing a personal image is further given importance by the participants, this research carried out a field study on The Minister of Health of The Republic of Turkey, Dr. Fahrettin Koca, whose statements about the Covid-19 pandemic are eagerly anticipated, advice and recommendations are listened to curiously, social media accounts are followed intensively. Through using the random sampling technique, the opinions of the 447 students studying at Uşak University Faculty of Communication were taken with the online questionnaire in the study according to the field research method. Participants were asked to state a general opinion about image and personal image issues, and later, in line with the data obtained from the students, the importance level of the 
factors making up the Health Minister Prof. Dr. Fahrettin Koca's image was tried to be revealed.

According to the research results, the participants were asked, "What is your opinion about the personal image?" to reveal their personal image perceptions. The answers show that the participants mostly perceive the personal image concept as "personality reflection of the individual, the way the person is perceived, and the representation of a person".

When the appearance factors affecting the personal image of Health Minister Fahrettin Koca are evaluated in general, "his kindness" is stated as the most important feature among the image features forming the individual vision of Health Minister Fahrettin Koca, while "his medium height" is given the least importance by the participants. According to the findings regarding the importance of non-verbal communication factors affecting the personal image of Health Minister Fahrettin Koca, among the non-verbal communication features composing the individual vision of Health Minister Fahrettin Koca, "Using Mimics While Talking" is the most important feature, while the least important characteristic is "Walking Style ". Considering the verbal communication factors affecting the personal image of Health Minister Fahrettin Koca, while "speaking style" is the most significant feature, "The intensity of his voice" stands out as the least important feature.

While "self-esteem" was the most important among the character traits making up the personal image of Health Minister Fahrettin Koca, "piety" is seen as the least important feature.

Seven factors that form individual images were determined in the study. To define the significance of these factors in the personal image formation, the participants were asked, which of the following options do you think constitutes the individual image most? It was found that the participants saw characteristics such as body language, the colors they used, the way they walk and sit as the most significant factor forming their image.

Health Minister Fahrettin Koca's image over the participants is mostly positive. To the participants, Fahrettin Koca is sympathetic, paternal, sincere, reliable, and honest. The most significant image characteristics of Health Minister Fahrettin Koca are "his kindness," "his speaking style," "his gestures," "his listening skill," "his experience," and "his sincerity." It was observed that those who attach importance to the verbal communication and nonverbal communication style of the individual in the personal image forma- 
tion also pay attention to the character, competence, and behavioral attitude characteristics. Regarding gender, women pay more attention to image, non-verbal, and other communication features than men. When the relationship between income and personal image is evaluated, it is seen that participants with higher income levels attach less importance to character and attitude factors. It is among the findings that marital status does not affect the significance given to the personal image.

When the results of the study were evaluated in general, it was concluded that the personal image of Health Minister Fahrettin Koca was mostly positive in the perception of the students of the Faculty of Communication at Uşak University. The findings have revealed that verbal and non-verbal communication factors and character factors were too efficient in positive image formation.

\section{Kaynakça / References}

Ak, M. (1996). Firmalarda kurumsal kimlik. İstanbul Üniversitesi İletişim Fakültesi Dergisi, 3, 193-197.

Arjen B. (2009). Becoming a better politician Political skills manual. Alfred Mozer Stichting

Ask Any Difference. (t.y.) Main page. 09.06.2020 tarihinde https://askanydifference.com/adresinden erişilmiştir.

Ayhan, D. Y. ve Karatepe, O. (1999). Halkla ilişkiler çalışmaları. İstanbul: Bilgi Yayınevi.

Barutçugil, İ. (2006). Yöneticinin yönetimi. Kariyer Yayıncllı, İstanbul.

Cambridge Dictionary. (t.y). Main page. 05.07.2020 tarihinde https://dictionary.cambridge.org adresinden erişilmiştir.

Canöz, K. ve Canöz, N. (2014). Cumhurbaşkanı Abdullah Gül'ün kişisel imajının ögelerini belirlemeye yönelik bir saha araştırması. Türkiyat Araştırmaları Dergisi, 35, 401-428.

Çakır, Ö. (2005). Profesyonel yaşamda kişisel imaj ve sosyal yaşam etiketi. Yapı Kredi Yayınları, İstanbul.

Dincer, M. K. (1998). İş yaşamında ve özel yaşamda kişisel imaj. İstanbul: Alfa Yayınları,

Ferrell. M. Z. (1981). Criticisms of the dominant perspective on organizations. The Sociological Quarterly, 22, 181 - 205.

Gemlik, N. ve Sığrı, Ü., (2007). Kurum İmajı analizi ve bir belediye üzerindeki uygulamanın değerlendirilmesi. İstanbul Ticaret Üniversitesi Sosyal Bilimler Dergisi, 11, 267-282. 
Hassin R., ve Trope, Y. (2000). Facing faces: Studies on the cognitive aspects of physiognomy. Journal of Personality and Social Psychology, 78 (5), 837-852.

International Foundation for Social Democracy, Netherlands.

Kire S., ve Aleksandar J.(2014). The role of image in the political campaigns. International Journal of Scientific \& Engineering Research, 5 (6), 599-603.

Kurbanoğlu, S.S. (2004). Öz-yeterlilik inancı ve bilgi profesyonelleri için önemi. Bilgi Dünyası, 5(2), 137-152.

Linkemer, B. (1997). Profesyonel imaj yaratmak. (Çev. N Gürbilek), Rota Yayınları, İstanbul.

Oržekauskas, P., ve Šmaižienè I. (2007) Public image and reputation management: Retrospective and actualities.Viešoji Politika Ir Administravimas, 19, 90-97.

Özer, A. (2008). 21. yüzyılda yönetim ve yöneticiler. Nobel Yayın, Ankara.

Peker, Ö., Aytürk N. (2002). Yönetim becerileri. Yargi Yay., Ankara

Peltekoğlu, F. B. (1997). Kurumsal iletişim sürecinde imajin yeri. İstanbul Üniversitesi İletişim Fakültesi Dergisi, 4, 125-145.

Poon Teng Fatt,J. (1998). Nonverbal communication and business success. Management Research News, 21(4/5), 1-10.

Positive psychology (t.y). Main page. 08.06.2020 tarihinde positivepsychology.com adresinden erişilmiştir.

Rao, H. (1994). The social construction of reputation: Certification contests, legitimation, and the survival of organization in the american automobile industry: 1895 - 1912, Strategic Management Journal, 15, 29 - 44.

Rasband, J. (2000). Power of personal appearance. Conselle L.C. I Institute of Image Management, www.conselle.com adresinden erişilmiştir.

Ray, S. (2011). An insight into the vision of charismatic leadership: Evidence from recent administrative change in West Bengal province of India.European Journal of Business and Management, 3(9), 55-67.

Rivers, W. L. (1982). The other government: Power and the Washington Media. New York: Universe Boks.

Robins, K. (1999). İmaj görmenin kültür politikası. (Çev. N. Türkoğlu), İstanbul: Ayrint Yayınları.

Rui, J. R., ve Stefanone M. A. (2013). Strategic image management online information, Communication \& Society, 16 (8) 1286-1305,

Sampson, E. (1995). İmaj faktörü. Çev. Hakan İgün, Rota Yayınları, İstanbul,

Taslak, S. ve Akın, M. (2005). Örgüt imajı üzerinde etkili olan faktörlere yönelik bir araştırma. Erciyes Üniversitesi, Sosyal Bilimler Enstitüsü Dergisi, 19, 263-294. 
Tengilimoğlu, D. ve Öztürk, Y. ( 2004 ). İsletmelerde halkla ilişkiler. Ankara: Seçkin Yayıncllık San. ve Tic. A.Ş.

Tolungüç, A. (2000). Turizmde tanıtım ve reklam. Ankara: MediaCat Yayınları.

Tosun, N.B. (2003). Kurumsal iletişim sürecinde reklamin ve imaj yönetiminin bütünleşik konumu. T.C. Marmara Üniversitesi İ.I.B.F. Dergisi, 18 (1), 173-191.

Türkkahraman, M. (2004).Günümüzün büyüsü imaj ve gerçek hayat. Sosyoloji Konferanslarn Dergisi, 30, 1-14.

Uztuğ, F. (1999). Siyasal marka seçim kampanyaları ve aday imajı. Ankara: MediaCat Yayınları.

Ünal Keskin,G. ve Orgun,F. (2006). Öğrencilerin öz etkinlilik- yeterlilik düzeyleri ile başa çıkma stratejilerinin incelenmesi. Anotolian Journal of Psychiatry, 7, 2-99.

Ünüsan Ç., ve Sezgin M. (2005). Turizmde strateji eksenli pazarlama iletişimi. İkia Yayıncllik, Konya.

Whetten, D. A., Mackey, A. (2002). A social actor conception of organizational identity and its implications for the study of organizational reputation. Business E Society, 41(4), 393-414.

Wright, H., Fill, C. (2001) Corporate images: Attributes and the U.K. pharmaceutical industry. Corporate Reputation Review, 4(2), 99-110.

Yıldız, N.(2002). Türkiye'de siyasetin yeni biçimi-liderler, imajlar, medya. Phoenix Yayınları: Ankara.

\section{Kaynakça Bilgisi / Citation Information}

Acar Şentürk, Z. ve Mutlu, A. (2020). Covid - 19 Sürecinde Türkiye Cumhuriyeti Sağlık Bakanı Fahrettin Koca'nın kişisel imaj ögelerini belirlemeye yönelik bir saha araştırması. OPUSUluslararası Toplum Araştırmaları Dergisi, 16(32), 4875-4906. DOI: 10.26466/opus. 817635 